\title{
PERENCANAAN PEMBELAJARAN BERBASIS KARAKTER
}

\author{
M. Nadzir \\ (Dosen IAIN Sunan Ampel Surabaya)
}

\begin{abstract}
Abstrak
Tulisan ini berupaya mendeskripsikan konsep perencanaan pembelajaran berbasis karakter. Perencanaan pembelajaran berbasis karakter merupakan seperangkat materi dan alat yang dipersiapkan guru ketika akan mengajar dengan mengedepankan aspek afektif dan nilai-nilai karakter yang luhur dalam perencanaannya untuk diinternalisasikan ke dalam diri murid-muridnya. Perencanaan pembelajaran berbasis karakter adalah model perencanaan dalam pembelajaran yang mengedepankan aspek penanaman nilai-nilai moral atau karakter bagi peserta didik. Ada banyak dimensi yang harus diperhatikan dalam menyusun perencanaan pembelajaran berbasis karakter. Perencanaan pebelajaran berbasis karakter sangat bermanfaat bagi stakeholders pembelajaran Karakter.
\end{abstract}

Kata Kunci: Perencanaan, Pembelajaran dan Karakter. 


\section{A. Pendahuluan}

Perencanaan pembelajaran merupakan suatu dokumen rasional yang disusun berdasarkan hasil analisis sistematis tentang perkembangan peserta didik dengan tujuan agar pembelajaran lebih efektif dan efisien sesuai dengan tuntutan kebutuhan siswa-siswi dan masyarakat. Pelaksanaan kegiatan pembelajaran yang baik memerlukan perencanaan program yang baik pula. Itu berarti keberhasilan belajar siswa-siswi sangat ditentukan oleh perencanaan yang dibuat guru. ${ }^{1}$

Oleh karena itu, penyusunan perencanaan pembelajaran harus dilakukan oleh guru pada saat akan melaksanakan tugasnya dalam membelajarkan siswa-siswi. Artinya, guru tidak akan dapat mengajar dengan optimal apabila tidak memiliki persiapan yang dikembangkan dalam perencanaan pembelajaran. Dalam tulisan ini disajikan pembahasan mengenai konsep dasar perencanaan pembelajaran berbasis karakter. Konsep dasar perencanaan pembelajaran berbasis karakter mencakup pengertian perencanaan pembelajaran berbasis karakter, dimensi, dan manfaat perencanaan pembelajaran berbasis karakter.

\section{B. Pengertian Perencanaan Pembelajaran Berbasis Karakter}

Perencanaan pembelajaran merupakan sesuatu hal yang penting bagi guru dalam menjalankan tugasnya. Perencanaan pembelajaran adalah proyeksi tentang sesuatu yang akan dilakukan oleh guru dalam proses belajar mengajar. Pembelajaran akan lebih optimal jika guru terlebih dahulu menyiapkan perencanaan pembelajaran. Perencanaan pembelajaran perlu dilakukan oleh guru untuk mengkoordinasikan komponen-komponen pembelajaran. Perencanaan pembelajaran berbasis kararkter berarti menyusun rencana pembelajaran yang lebih mengedepankan aspek sikap, perilaku, karakter yang akan diinternalisasikan ke dalam diri peserta didik.

${ }^{1}$ Hanun Asroha, Perencanaan Pembelajaran (Surabaya: Kopertais IV-Pemprov Jatim, 2010), 1. 


\section{Definisi Perencanaan}

Dalam bahasa Inggris, perencanaan dikenal dengan istilah planning, artinya serangkaian kegiatan yang akan dilakukan di masa yang akan datang. Lesson plan berarti perencanaan pembelajaran. Selain plan juga dikenal istilah design (baca: desain) yang dapat juga diartikan perencanaan. Ada juga yang mengartikan design sebagai "persiapan". 2

Perencanaan yang dalam ilmu manajemen disebut planning, adalah persiapan menyusun suatu keputusan berupa langkah-langkah penyelesaian suatu masalah atau pelaksanaan suatu pekerjaan yang terarah pada pencapaian tujuan tertentu. Secara sederhana perencanaan adalah pemikiran sebelum pelaksanaan suatu tugas. ${ }^{3}$

Dalam bukunya berjudul Administrative Action Techniques of Organization and Management, William H. Newman, sebagai mana dikutip oleh Majid, mengemukakan bahwa "perencanaan adalah menentukan apa yang akan dilakukan. Perencanaan mengandung rangkaian-rangkaian putusan yang luas dan penjelasan-penjelasan dari tujuan, penentuan kebijakan, penentuan program, penentuan metodemetode dan prosedur tertentu dan penentuan kegiatan berdasarkan jadwal sehari-hari". ${ }^{4}$

Sementara itu, Terry menyatakan bahwa perencanaan adalah menetapkan pekerjaan yang harus dilaksanakan oleh kelompok untuk mencapai tujuan yang digariskan. Perencanaan mencakup kegiatan pengambilan keputusan. Untuk itu diperlukan kemampuan untuk mengadakan visualisasi dan melihat ke depan guna merumuskan suatu pola tindakan untuk masa mendatang. ${ }^{5}$

Perencanaan berarti menyusun langkah-langkah penyelesaian suatu masalah atau pelaksanaan suatu pekerjaan yang terarah pada pencapaian tujuan tertentu. Dalam hal ini perencanaan mencakup rangkaian kegiatan untuk menentukan tujuan umum (goal) dan tujuan

\footnotetext{
${ }^{2}$ Ahmad Rohani, Pengelolaan Kelas (Jakarta: Rineka Cipta, 2004), 67.

${ }^{3}$ Ahmad Rohani, Pengelolaan Kelas, 66-67.

${ }^{4}$ A. Madjid, Perencanaan Pembelajaran (Bandung: PT Remaja Rosdakarya, 2006), 15.

${ }^{5}$ Terry dalam A. Madjid, Perencanaan Pembelajaran, 16. 
khusus (objektivitas) suatu organisasi atau lembaga penyelenggara pendidikan, berdasarkan dukungan informasi yang lengkap. ${ }^{6}$

Pengertian tersebut di atas bermakna bahwa perencanaan adalah usaha menyeleksi dan menghubungkan sesuatu degan kepentingan masa yang akan datang serta usaha untuk mencapainya. Senada dengan ini, Hamzah B. Uno mendefinisikan perencanaan sebagai hubungan antara yang ada sekarang (what is) dengan bagaimana seharusnya (what should be) yang bertalian dengan kebutuhan, penentuan tujuan, prioritas program, dan alokasi sumber. ${ }^{7}$

Perencanaan dapat juga didefinisikan sebagai suatu cara untuk mengantsipasi dan menyeimbangkan perubahan. Menurut Uno definisi ini mengasumsikan bahwa perubahan selalu terjadi. Perubahan lingkungan harus selalu diantisipasi sehingga perubahan berimbang dengan perubahan dalam pembelajaran di sekolah atau madrasah. ${ }^{8}$

Dengan demikian, perencanaan memiliki tiga makna. Pertama, perencanaan adalah usaha mencari wujud yang akan datang serta usaha untuk mencapainya. Kedua, perencanaan bermakna usaha menghilangkan kesenjangan antara keadaan masa sekarang dengan masa yang akan datang. Ketiga, perencanaan adalah usaha merubah keadaan agar sejalan dengan keadaan lingkungan yang juga berubah. ${ }^{9}$

\section{Definisi Pembelajaran}

Pembelajaran adalah suatu proses yang dilakukan oleh para guru dalam membimbing, membantu, dan mengarahkan peserta didik untuk memiliki pengalaman belajar. Dengan kata lain pembelajaran adalah suatu cara untuk mempersiapkan pengalaman belajar bagi peserta didik. Pembelajaran adalah kegiatan yang di dalamnya terkandung dua unsur pokok, yaitu unsur kegiatan guru dan siswa. ${ }^{10}$

\footnotetext{
${ }^{6}$ Nawawi dalam Hanun Asroha, Perencanaan Pembelajaran, 4.

${ }^{7}$ Hamzah B. Uno, Perencanaan Pembelajaran (Jakarta: Bumi Aksara, 2008), 82.

${ }^{8}$ Hamzah B. Uno, Perencanaan Pembelajaran, 83.

${ }^{9}$ Hanun Asroha, Perencanaan Pembelajaran, 5.

${ }^{10}$ Hanun Asroha, Perencanaan Pembelajaran, 5.
} 
Dalam Proses pembelajaran, yang sering disebut juga sebagai kegiatan belajar mengajar, di satu pihak guru melakukan kegiatan atau perbuatan yang membawa anak ke arah tujuan tertentu. Dalam konteks itu, siswa melakukan serangkaian kegiatan-kegiatan yang disediakan oleh guru, yaitu kegiatan belajar yang terarah pada tujuan yang akan dicapai.

Pembelajaran sebisa mungkin didesain dalam keadaan yang kondusif, agar guru dan siswa merasa nyaman dalam kegiatan belajar mengajarnya. Kondusifitas keadaan belajar mengajar sangat tergantung pada ketersediaan fasilitas dan perencanaan sebelum melaksanakan pembelajaran. Apabila fasilitas pembelajaran memadai dan perencanaan pembelajaran dilakukan secara cukup, maka suasana belajar mengajar niscaya akan kondusif dan efektif.

\section{Definisi Perencanaan Pembelajaran}

Perencanaan pembelajaran merupakan sesuatu yang dipersiapkan secara sistematis dalam suatu pembelajaran yang akan dimanifestasikan bersama-sama peserta didik. Dalam bahasa Madjid, perencanaan pembelajaran adalah proses penyusunan materi pelajaran, penggunaan media pengajaran, penggunaan pendekatan dan metode pengajaran, dan penilaian dalam suatu alokasi waktu yang akan dilaksanakan pada masa tertentu untuk mencapai tujuan yang telah ditentukan. ${ }^{11}$

Konsep tersebut di atas mengandung dua pemikiran utama, yaitu proses pengambilan keputusan dan pengetahuan profesional tentang proses pengajaran. Keputusan yang diambil oleh guru bisa bemacam-macam, mulai dari yang sederhana sampai pada tingkat yang komplek. Keputusan tingkat sederhana, misalnya, pengorganisasian aktivitas kelas; sedangkan keputusan pada tingkat komplek menetukan apa yang akan dipelajari anak.

Berdasarkan uraian di atas, konsep perencanaan pembelajaran dapat dilihat dari berbagai sudut pandang, yaitu:

a. Perencanaan pembelajaran sebagai teknologi adalah suatu perencanaan yang mendorong penggunaan teknik-teknik yang

\footnotetext{
${ }^{11}$ A. Madjid, Perencanaan Pembelajaran, 17. 
dapat mengembangkan tingkah laku kognitif dan teori-teori konstruktif terhadap solusi dan problem-problem pengajaran.

b. Perencanaan pembelajaran sebagai suatu sistem adalah sebuah susunan dari sumber-sumber dan prosedur-prosedur untuk menggerakkan pembelajaran. Pengembangan sistem pengajaran melalui proses yang sistematik selanjutnya diimplementasikan dengan mengacu pada sistem perencanaan itu.

c. Perencanaan pembelajaran sebagai sebuah disiplin adalah cabang pengetahuan yang memperhatikan hasil-hasil penelitian dan teori tentang strategi pengajaran dan implementasinya terhadap strategi tersebut.

d. Perencanaan pembelajaran sebagai sains (science) adalah mengkreasi secara detail spesifikasi dari pengembangan, implementasi, evaluasi, dan pemeliharaan akan situasi maupun fasilitas pembelajaran terhadap unit-unit yang luas maupun sempit dari materi dengan segala kompleksitasnya.

e. Perencanaan pembelajaran sebagai sebuah proses adalah pengembangan pengajaran secara sistematis yang digunakan secara khusus atas dasar teori-teori pembelajaran dan pengajaran untuk menjamin kualitas pembelajaran. Dalam perencanaan ini dilakukan analisis kebutuhan dari proses belajar dengan alur yang sistematis untuk mencapai tujuan pembelajaran. Termasuk di dalamnya melakukan evaluasi terhadap materi pelajaran dan aktivitasaktivitas pengajaran.

f. Perencanaan pembelajaran sebagai sebuah realitas adalah ide pengajaran dikembangkan dengan memberikan hubungan pengajaran dari waktu ke waktu dalam suatu proses yang dikerjakan dengan mengecek secara cermat bahwa semua kegiatan telah sesuai dengan tuntutan sains dan dilaksanakan secara sistematis. ${ }^{12}$

Dengan mengacu kepada berbagai sudut pandang tersebut di atas, maka perencanaan pembelajaran harus sesuai dengan konsep pendidikan dan pengajaran yang dianut dalam kurikulum. Penyusunan program pengajaran sebagai sebuah proses, disiplin ilmu pengetahuan, realitas,

${ }^{12}$ Hanun Asroha, Perencanaan Pembelajaran, 6-7. 
sistem dan teknologi pembelajaran bertujuan agar pelaksanaan pembelajaran berjalan dengan efektif dan efisien. Kurikulum khususnya silabus menjadi acuan utama dalam penyusunan perencanaan program pengajaran, namun kondisi ssekolah/madrasah dan lingkungan sekitar, kondisi siswa dan guru merupakan hal penting yang tidak boleh diabaikan.

\section{Definisi Perencanaan Pembelajaran Berbasis Karakter}

Sebelum melaksanakan proses belajar mengajar, diperlukan sebuah perencanaan yang matang agar pembelajaran menjadi efektif. Oleh karena itu perencanaan pembelajaran sangat diperlukan dan harus dilakukan oleh guru ketika akan mengajar di kelas. Perencanaan pembelajaran merupakan seperangkat materi dan alat yang dipersiapkan dalam rangka menopang proses pembelajaran yang efektif dan efisien.

Apabila seorang guru mau menanamkan nilai-nilai karakter kepada murid-muridnya, maka perencanaan pembelajaran yang disusun harus berbasis karakter. Perencanaan pembelajaran berbasis karakter merupakan seperangkat materi dan alat yang dipersiapkan guru ketika akan mengajar dengan mengedepankan aspek afektif dan nilai-nilai karakter yang luhur dalam perencanaannya untuk diinternalisasikan ke dalam diri murid-muridnya. Perencanaan pembelajaran berbasis karakter adalah model perencanaan dalam pembelajaran yang mengedepankan aspek penanaman nilai-nilai moral-karakter bagi peserta didik.

Pendidikan karakter merupakan usaha untuk membentuk kebiasaan baik anak sejak usia dini, atau suatu sistem penanaman nilai-nilai karakter yang meliputi komponen pengetahuan, kesadaran atau kemauan, dan tindakan untuk melaksanakan nilai-nilai tersebut, baik terhadap Tuhan Yang Maha Esa, diri sendiri, sesama, lingkungan, maupun kebangsaan sehingga menjadi insan kamil ${ }^{13}$ (manusia yang sempurna). Pendidikan karakter dalam praktik tidak hanya diselenggarakan dalam rangka membentuk moral knowing,

${ }^{13}$ Ratna Megawangi, Pendidikan Karakter: Solusi yang Tepat untuk Membangun Bangsa (Jakarta: Indonesia Heritage Foundation, 2004), 23.

Jurnal Pendidikan Agama Islam

Volume 02 Nomor 02 November 2013

Hal $344-352$ 
akan tetapi pendidikan karakter harus mampu membentuk moral feeling dan moral action. ${ }^{14}$ Konsep pembentukan karakter melalui perencanaan pembelajaran berbasis karakter harus menjadi ruh dari pembangunan bangsa.

\section{Urgensi Perencanaan Pembelajaran Berbasis Karakter}

Perencanaan pembelajaran memainkan peran penting dalam memandu guru untuk melaksanakan tugas sebagai pendidik dalam melayani kebutuhan belajar siswa-siswinya. Perencanaan pembelajaran juga dimaksudkan sebagai langkah awal sebelum proses pembelajaran berlangsung. Dengan demikian, perencanaan pembelajaran digunakan sebagai pedoman kegiatan guru dalam mengajar dan pedoman siswasiswi dalam kegiatan belajar yang disusun secara sistematis.

Perencanaan pembelajaran seharusnya dipandang sebagai suatu alat yang dapat membantu para pengelola pendidikan lebih berdaya guna dalam melaksanakan tugas dan fungsinya. Perencanaan dapat menolong pencapaian suatu sasaran secara lebih ekonomis, tepat waktu, dan memberi peluang untuk lebih mudah dikontrol dalam pelaksanaannya.

Oleh karena perencanaan pembelajaran sebagai langkah awal dalam kegiatan pembelajaran, ia menempati posisi yang amat penting dan menentukan. Urgensi perencanaan pembelajaran -antara lain- adalah: 1. menunjukkan arah kegiatan, 2. memperkirakan apa yang akan terjadi dalam pembelajaran, 3. menentukan cara terbaik untuk mencapai tujuan pembelajaran, 4. menentukan skala prioritas, dan 5. menentukan alat pengukur atau standar untuk mengadakan pengawasan atau evaluasi kinerja, sasaran, dan kegiatan usahanya.

Perencanaan pembelajaran berbasis karakter sangat penting untuk memberikan arahan pelaksanaan pembelajaran berbasis karakter. Pembelajaran berbasis karakter berarti model pembelajaran yang mengarusutamakan pembentukan karakter tertentu yang baik dan luhur bagi peserta didik. Pembentukan karakter tidak mungkin dapat dilakukan

\footnotetext{
${ }^{14}$ Lickona, dalam Hanun Asroha, "Kabijakan Nasional dan Paradigma Pendidikan Karakter di Indonesia", 4. Makalah disampaikan pada acara International Conference dengan tema Expressions of Islam in Recent Southeast Asian's Politics, di Gedung Rektorat IAIN Suanan Ampel pada 11 Oktober 2010.
} 
dengan cara hanya memberikan ceramah saja, tetapi harus dibiasakan dalam perilaku.

\section{Dimensi Perencanaan Pembelajaran Berbasis Karakter}

Dimensi perencanaan pembelajaran berbasis karakter berkaitan dengan cakupan dan sifat dari beberapa karakteristik yang ditemukan dalam perencanaan pembelajaran. ${ }^{15}$ Hal ini memungkinkan diadakannya perencanaan pembelajaran karakter secara komprehensif yang meliputi:

\section{Signifikansi}

Perencanaan pembelajaran berbasis karakter harus melihat aspek atau tingkat signifikansinya. Ini dikaitkan dengan tujuan pendidikan yang diajukan dan signifikansi dapat ditentukan berdasarkan kriteriakriteria yang dibangun selama proses perencanaan pembelajaran.

\section{Feasibilitas}

Perencanaan pembelajaran berbasis karakter harus disusun berdasarkan pertimbangan realistik, baik yang berkaitan dengan biaya maupun pengimplementasiannya.

\section{Relevansi}

Konsep relevansi berkaitan dengan jaminan bahwa perencanaan pembelajaran berbasis karakter memungkinkan penyelesaian persoalan secara lebih spesifik pada waktu yang tepat agar dapat dicapai tujuan spesifik secara optimal.

\section{Kepastian}

Konsep kepastian diharapkan dapat mengurangi kejadian-kejadian yang tidak terduga di luar perencanaan. Apa yang direncanakan sebisa mungkin terjadi dalam pelaksanaan. Perencanaan yang baik adalah perencanaan yang benar-benar dilaksanakan dalam praktik.

\section{Ketelitian}

Prinsip utama yang perlu diperhatikan ialah agar perencanaan pembelajaran berbasis karakter disusun dalam bentuk yang sederhana, serta perlu diperhatikan secara sensitif kaitan yang pasti antar berbagai komponen.

\footnotetext{
${ }^{15}$ Harjanto, Perencanaan Pengajaran (Jakarta: Rineka Cipta, 2006), 4-5. 


\section{Adaptabilitas}

Perencanaan pembelajarn berbasis karakter harus bersifat dinamis, sehingga perlu senantiasa mencari informasi sebagai umpan balik. Penggunaan berbagai proses memungkinkan perencanaan yang fleksibel atau adaptable dan dapat dirancang untuk menghindari halhal yang tidak diharapkan.

\section{Waktu}

Faktor yang berkaitan dengan waktu cukup banyak, selain keterlibatan perencanaan dalam memprekdisi masa depan, juga validasi dan reliabilitas analisis yang dipakai, serta kapan untuk menilai kebutuhan kependidikan masa kini dan masa mendatang.

\section{Monitoring}

Monitoring merupakan proses mengembangkan kriteria untuk menjamin bahwa komponen pembelajaran bekerja secara efektif. ${ }^{16}$

\section{Isi Perencanaan}

Isi perencanaan merujuk pada hal-hal yang akan direncanakan. Perencanaan pembelajaran yang baik perlu memuat:

a. Tujuan yang diinginkan, atau bagaimana cara mengorganisasi aktivitas belajar dan layanan-layanan pendukungnya.

b. Program dan layanan, atau bagaimana cara mengorganisasi aktivitas belajar dan layanan-layanan pendukungnya.

c. Tenaga manusia, yakni mencakup cara-cara mengembangkan prestasi, spesialisasi, perilaku, kompetensi, maupun kepuasan mereka.

d. Keuangan, meliputi rencana pengeluaran dan rencana penerimaan.

e. Bangunan fisik mencakup tentang cara-cara penggunaan pola distribusi dan kaitannya dengan pengembangan psikologis.

f. Struktur organisasi, maksudnya bagaimana cara mengorganisasi dan memanaje operasi serta mengawasi program dan aktivitas kependidikan yang direncanakan.

g. Konteks sosial atau elemen-elemen lainnya yang perlu dipertimbangkan dalam perencanaan pembelajaran. ${ }^{17}$

${ }^{16}$ Lihat Evi Fatimatur Rusydiyah, Perencanaan Pembelajaran (Surabaya: LAPISAUSAID, 2009), 8-9

${ }^{17}$ Disarikan dari Hanun Asroha, Perencanaan Pembelajaran, 8-9. 


\section{E. Manfaat Perencanaan Pembelajaran Berbasis Karakter}

Perencanaan pembelajaran memainkan peran penting dalam memandu guru untuk melaksanakan tugas sebagai pendidik dalam melayani kebutuhan belajar siswannya. Perencanaan pembelajaran juga dimaksudkan sebagai langkah awal sebelum proses pembelajaran berlangsung. Terdapat beberapa manfaat perencanaan pembelajaran dalam proses belajar mengajar yaitu:

1. Sebagai petunjuk arah kegiatan dalam mencapai tujuan.

2. Sebagai pola dasar dalam mengatur tugas dan wewenang bagi setiap unsur yang terlibat dalam kegiatan.

3. Sebagai pedoman kerja bagi setiap unsur, baik unsur guru maupun unsur murid.

4. Sebagai alat ukur efektif tidaknya suatu pekerjaan, sehingga setiap saat diketahui ketepatan dan kelemahan kinerja.

5. Untuk bahan penyusunan data agar terjadi keseimbangan kerja.

6. Untuk menghemat waktu, tenaga, alat-alat dan biaya.

Sementara itu, penerapan konsep dan prinsip pembelajaran berbasis kompetensi diharapkan bermanfaat untuk:

1. Menghindari duplikasi dalam memberikan materi pelajaran. Dengan menyajikan materi pelajaran yang benar-benar relevan dengan kompetensi yang ingin dicapai, dapat dihindari terjadinya duplikasi dan pemberian materi pelajaran yang terlalu banyak.

2. Mengupayakan konsistensi kompetensi yang ingin dicapai dalam mengajarkan suatu mata pelajaran. Dengan kompetensi yang telah ditentukan secara tertulis, siapapun yang mengajarkan mata pelajaran tertentu tidak akan bergeser atau menyimpang dari kompetensi dan materi yang telah ditentukan.

3. Meningkatkan pembelajaran sesuai dengan kebutuhan, kecepatan dan kesempurnaan siswa.

4. Membantu mempermudah pelaksanaan akreditasi. Pelaksanaan akreditasi akan lebih dipermudah dengan menggunakan tolok ukur standar kompetensi.

5. Memperbaharui sistem evaluasi dan laporan hasil belajar siswa. Dalam pembelajaran berbasis kompetensi, keberhasilan siswa diukur dan dilaporkan berdasar pencapaian kompetensi atau sub kompetensi 
tertentu, bukan didasarkan atas perbandingan dengan hasil belajar siswa yang lain.

6. Memperjelas komunikasi dengan siswa tentang tugas, kegiatan, atau pengalaman belajar yang harus dilakukan, dan cara yang digunakan untuk menentukan keberhasilan belajarnya.

7. Meningkatkan akuntabilitas publik. Kompetensi yang telah disusun, divalidasikan, dan dikomunikasikan kepada publik, sehingga dapat digunakan untuk mempertanggung jawabkan kegiatan pembelajaran kepada publik.

8. Memperbaiki sistem sertifikasi. Dengan perumusan kompetensi yang lebih spesifik dan terperinci, sekolah/madrasah dapat mengeluarkan sertifikat atau transkrip yang menyatakan jenis dan aspek kompetensi yang dicapai.

Pembelajaran berbasis kompetensi mengarahkan peserta didik untuk dapat melakukan sesuatu secara berkompeten. Kompeten artinya dapat mengerjakan suatu tugas atau pekerjaan sesuai dengan standar kompetensi yang telah ditetapkan. Mereka diharapkan dapat menggunakan kemampuan yang dimilikinya untuk memecahkan masalah atau melaksanakan tugas dengan kondisi yang berbeda.

Batasan tersebut berdampak pada kegiatan pembelajaran yang diarahkan untuk memberdayakan semua potensi peserta didik untuk menguasai kompetensi yang diharapkan. Hal ini akan berakibat adanya konsep perencanaan pembelajaran yang spesifik, yaitu merencanakan pembelajaran dengan mengarah pada pembentukan siswa-siswi untuk berkompeten.

Menurut Majid, ciri khas program pembelajaran berbasis kompetensi mengandung empat unsur pokok, yakni: 1. pemilihan kompetensi yang sesuai, 2. spesifikasi indikator-indikator evaluasi untuk menentukan keberhasilan pencapaian kompetensi, 3. pengembangan sistem pengajaran, dan 4. penilaian. ${ }^{18}$

Berkaitan dengan kepentingan di atas, perencanaan pembelajaran berbasis kompetensi tepat menggunakan langkahlangkah pengembangan pembelajaran yang terdiri atas: 1 .

${ }^{18}$ A. Madjid, Perencanaan Pembelajaran. 
menentukan spesifikasi asumsi-asumsi atau preposisi yang mendasar, 2. mengidentifikasi kompetensi, 3. menggambarkan secara spesifik kompetensi-kompetensi, 4. menentukan tingkattingkat kriteria dan jenis assessment, 5. mengelompokkan dan menyusun tujuan pembelajaran, 6. mendesain strategi pembelajaran, 7. mengorganisasi sistem pengelolaan, 8. melaksanakan percobaan program, 8. menilai desain program, dan 9. memperbaiki program. ${ }^{19}$

Dalam pada itu, perencanaan pembelajaran berbasis karakter akan memberikan beberapa nilai manfaat sebagai berikut:

1. Guru akan lebih mudah menanamkan nilai-nilai karakter tertentu ke dalam diri siswa berdasarkan perencanaan pembelajaran berbasis karakter yang sudah dipersiapkan.

2. Memungkinkan guru untuk memiliki panduan atau pedoman untuk melihat tercapai atau tidaknya pembangunan karakter yang diupayakan bagi siswanya.

3. Siswa akan terbantu memiliki karakter tertentu yang luhur melalui proses pembelajaran karakter yang sudah dipersiapkan dalam perencanaannya.

\section{F. Ruang Lingkup Perencanaan Pembelajaran Berbasis Karakter}

Perencanaan pembelajaran (desain instruksional) merupakan kegiatan organisasi instruksional (pembelajaran). Organisasi instruksional bertujuan untuk mengkoordinasikan komponen-komponen pembelajaran. Komponen organisasi instruksional yang dimaksud adalah: 1. tujuan pembelajaran, 2. materi pembelajaran, 3. metode pembelajaran, 4. langkah-langkah interaksi pembelajaran, 5. sumber belajar yang digunakan, 6. evaluasi pembelajaran.

Perencanaan pembelajaran mencakup kegiatan merumuskan tujuan pembelajaran, merumuskan isi/materi pelajaran yang harus dipelajari, merumuskan kegiatan belajar, dan merumuskan sumber belajar/media pembelajaran yang akan digunakan serta merumuskan evaluasi pembelajaran. Perencanaan pembelajaran merupakan kegiatan penting dalam pembelajaran, sehingga pembelajaran harus didesain secara sistematis dalam merumuskan tujuan, bagaimana karakteristik

\footnotetext{
${ }^{19}$ Evi Fatimatur Rusydiyah, Perencanaan Pembelajaran, 12.
} 
siswa-siswinya, bagaimana menentukan metodenya, bagaimana menentukan topiknya, dan bagaimana cara mengevalusinya.

Dalam buku perencanaan pembelajaran berbasis karakter ini, ruang lingkup yang menjadi pembahasan, antara lain: Memahami Pendidikan karakter, Konsep Dasar Perencanaan Pembelajaran Berbasis Karakter, Pendekatan dalam Pembelajaran Berbasis Karakter, Model Pembelajaran Berbasis Karakter, Kompetensi Dasar dan Indikator Pembelajaran Berbasis Karakter, Pengembangan Bahan Ajar Berbasis Karakter, Metode dan Media Pembelajaran Berbasis Karakter, Perangkat Perencanaan Pembelajaran Berbasis Karakter, Pekan Efektif dalam Pembelajaran, Program Tahunan dalam Pembelajaran, Program Semester dalam Pembelajaran, Silabus dalam Pembelajaran Berbasis Karakter, Penilaian dalam Pembelajaran Berbasis Karakter, Satuan Pembelajaran Berbasis Karakter, dan lain-lain.

\section{G. Kesimpulan}

Perencanaan pembelajaran merupakan sesuatu hal yang penting bagi guru dalam menjalankan tugasnya. Perencanaan pembelajaran memainkan peran penting dalam memandu guru untuk melaksanakan tugas sebagai pendidikan dalam melayani kebutuhan belajar siswannya. Perencanaan pembelajaran juga dimaksudkan sebagai langkah awal sebelum proses pembelajaran berlngsung.

Perencanaan pembelajaran merupakan proyeksi tentang sesuatu yang akan dilakukan oleh guru dalam proses belajar mengajar. Pembelajaran akan lebih optimal jika guru terlebih dahulu menyiapkan perencanaan pembelajaran. Perencanaan pembelajaran merupakan penyusunan program yang sistematis dalam suatu pembelajaran untuk mengkoordinasikan komponen-komponen pembelajaran, yang akan dimanifestasikan bersama-sama peserta didik. Perencanaan pembelajaran adalah proses penyusunan materi pelajaran, penggunaan media pengajaran, penggunaan pendekatan dan metode pengajaran, dan penilaian dalam suatu alokasi waktu yang akan dilaksanakan pada masa tertentu untuk mencapai tujuan yang telah ditentukan.

Perencanaan pembelajaran mengandung dua pemikiran utama, yaitu proses pengambilan keputusan dan pengetahuan profesional tentang 
proses pembelajaran. Keputusan yang diambil oleh guru bisa bemacammacam, mulai dari yang sederhana sampai pada tingkat yang komplek. Keputusan tingkat sederhana, misalnya, pengorganisasian aktivitas kelas; sedangkan keputusan pada tingkat komplek menentukan sesuatu yang akan dipelajari peserta didik.

Perencanaan pembelajaran berbasis karakter merupakan seperangkat materi dan alat yang dipersiapkan guru ketika akan mengajar dengan mengedepankan aspek afektif dan nilai-nilai karakter yang luhur dalam perencanaannya untuk diinternalisasikan ke dalam diri muridmuridnya. Perencanaan pembelajaran berbasis karakter adalah model perencanaan dalam pembelajaran yang mengedepankan aspek penanaman nilai-nilai moral-karakter bagi peserta didik. Ada banyak dimensi yang harus diperhatikan dalam menyusun perencanaan pembelajaran berbasis karakter. Perencanaan pebelajaran berbasis karakter sangat bermanfaat bagi stakeholders pembelajaran Karakter.

\section{DAFTAR PUSTAKA}

Ahmad Rohani, 2004, Pengelolaan Kelas (Jakarta: Rineka Cipta).

A. Madjid, 2006, Perencanaan Pembelajaran (Bandung: PT Remaja Rosdakarya).

Evi Fatimatur Rusydiyah, 2009, Perencanaan Pembelajaran (Surabaya: LAPIS-AUSAID).

Hanun Asroha, 2010, Perencanaan Pembelajaran (Surabaya: Kopertais IVPemprov Jatim).

Hanun Asroha, "Kabijakan Nasional dan Paradigma Pendidikan Karakter di Indonesia". Makalah disampaikan pada acara International Conference dengan tema Expressions of Islam in Recent Southeast Asian's Politics, di Gedung Rektorat IAIN Suanan Ampel pada 11 Oktober 2010.

Harjanto, 2006, Perencanaan Pengajaran (Jakarta: Rineka Cipta).

Hamzah B. Uno, 2008, Perencanaan Pembelajaran (Jakarta: Bumi Aksara). Ratna Megawangi, 2004, Pendidikan Karakter: Solusi yang Tepat untuk Membangun Bangsa (Jakarta: Indonesia Heritage Foundation). 